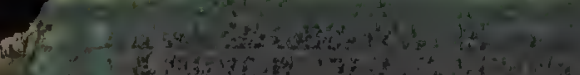

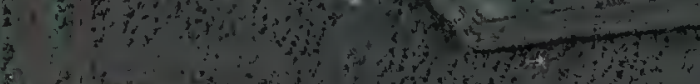
and (1) a and

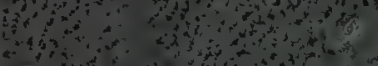

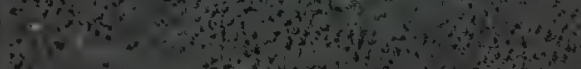
है 120

$$
\text { (5) }
$$




\section{The Dying Never Weep}

It is a striking fact-the dying never weep. The circle of sobbing, agonized bearts around poduces not one tear. Is it that he is insensible and stiff already in the chill of dissolution? That cannot be, for be asks for his fatber's hand, as if to gain strength in the mortal struggle, and leans on the breast of mother, brother nr sister, with still conscious affection; and, just before expiring, at eve, after a long day's con. verse with the Angel of Suminons, he says to his oldest brother-the last audible good night of earth-" Kiss me, kiss me !" It must be because the dying have reached a ooint too deep for our earthly erying and seeping. They are face to face with highor and holier beings, with the Father in reaven, and bis angel throng, led on by he Son himself; and what are griefs of a norning, tears of a dying farewell-be it hat they are shed by the dearest on earth -in that vision bright of immortal life and varlasting re-union." 


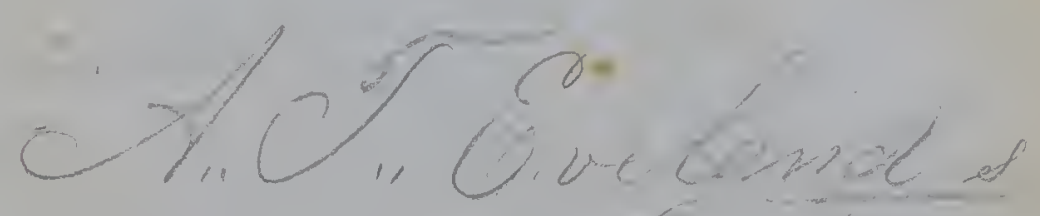

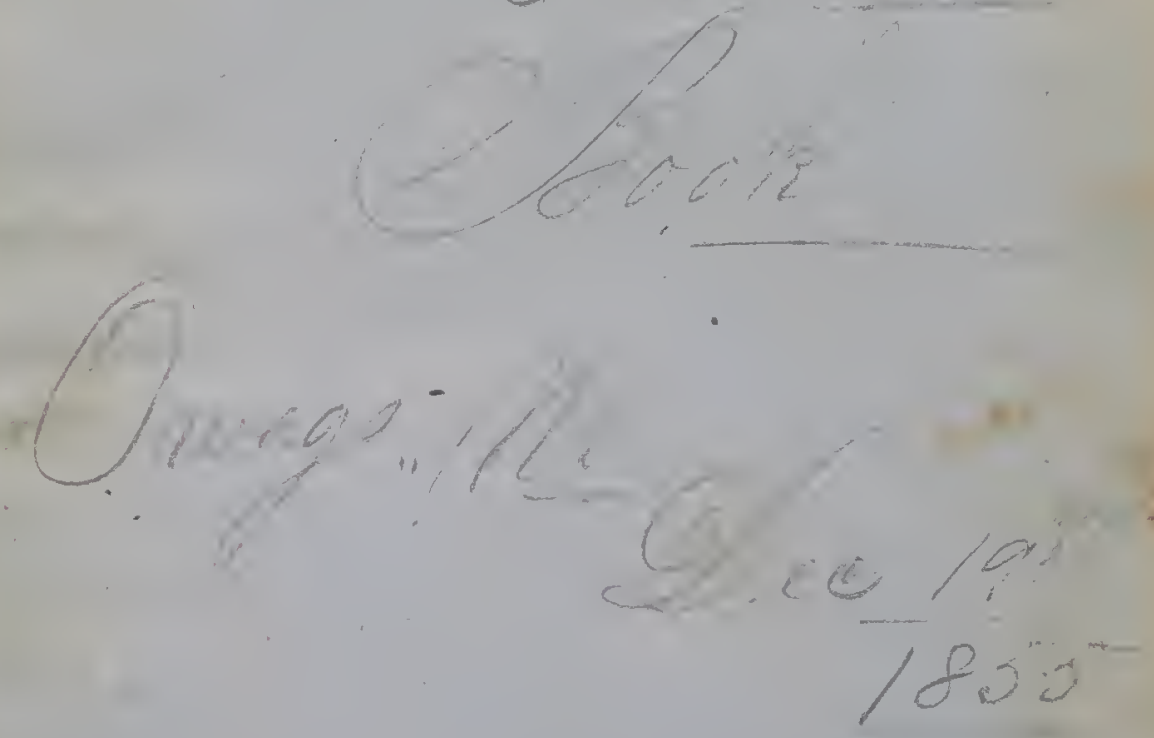


$\frac{21}{1 / 2}$

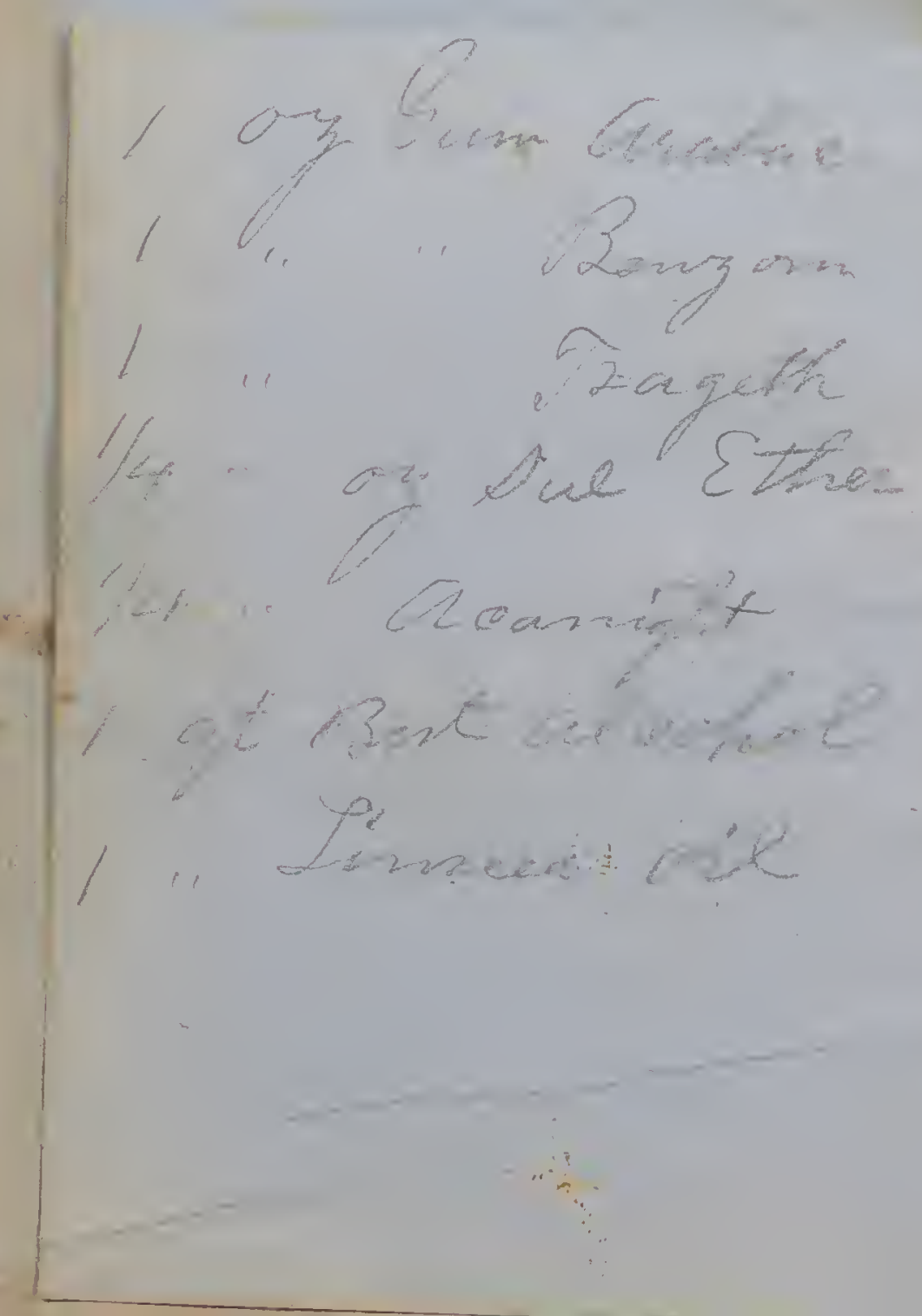




A Evelands Dairy the past year ha heen one of Tpirtuale a dvancerne nt tut commence 1858 with a slionger determination than cver of abandin ing all sin the lastyels I have at timesreguad ed Inngunty in nhy heast but by he helis of aod I hall brelik Ofoose from all sin and qrow up into christ my liveng head secret proyer has feen loo mueh forgott en butwe assis tirng grace of bod that shall be at tended too

Oureg. His

Ime st/dso 
juns Attended church at bongriegational and heard the per inr Bartlep discouse from Eyodes, and of th now there was a newhing ve 7 attended frayer meeting there roas a good influenee in the fubloth

Pis clay zuad siefs hud ar a tack of my cld complainht

- Fever \& cigue

11 Atended frayer weeterg at Bro soth vicho if was a precious * Ingetalle time of was the Houng converts neeting 
$16418 \tan / 858$

14 this Evening I heard the kew Mr Sierlingham reach in the baptist House from let 3 and the foist 6 verses the sermon urus to the fort. Some preacher now a days french un at they would hot practice

Midway Eve 15 this evening are the presence of the Lond was manifested to many souls we ez/ fe better on account of min and woman being lava to Hie fest interests of their aloud 
diet 1858

7 this day heard bro Gram preach tree and the fond was present to bless the people It in the evening a number f gould war - seeking the Lord

21 Bro Gram preccened. from form of $\$ 6$ verse and the sews Suicide behold hope he lowed him

Burch 1858

" sting yesterday, between $5 \times 6$ Mn I can Slate mi s entire consecration to yod have been a firofesson for upwards of ir wear of - Lever cental yesterday ivirendered must completely into the. 
wile of God tort I fave throlon misyself wpon tis merets ofe elcepts the 12000 ffering and alt is pancel of foy in the holy. IStost soufeck Love dwolles in my theart I an saved frop Lin. memorable 19. the maxely Is will te reme mbored call Etornity If lory to God in the hiqhest

Evening this has been a foy ous God has blesed me in wosking forthom Do dia dscer came this aftornown and this sevenung has feen the Ineatist meeting ave tiave got thad 
the coulter wac es crowded with penitent Souls the work has been progressing for 4 treats and it is us comment cuing. The Lord be prams mar 141858 Sabbath this has been a precious day to my soul the Lond vas in his sanctuary. to refresh hin beofite no of Sister Dormer til resent on how that veloved-Aister Loves to devil on her telexed. theme of perfect Love ir entire conte elution $H_{1} z_{c} \varepsilon$

Bracero His: 
1858

Friday the 2 nd This has been" a day of: fasting of prayer this is the fir lot day I ever abstained from all food until velum after flexed in doing fit I have freon refreshed this deny pom the presence of the Lond and citrous - Have \& arr tabooing under temporal ember rossments yet oc ere Gray glory the to Toad the Lord oninupoteth pine the

May 16 sabbath this day the Kevdohn Pier preached his first Sermon in 

Gurge from 2 nd

and the presence of the Lond was glorious manifested in thertuiled ing utatrefreshing. of believers and in the evening he reads from posclmo 30 .

may 30 Tho Sabbath

the ono sere floreated fount and from the 14

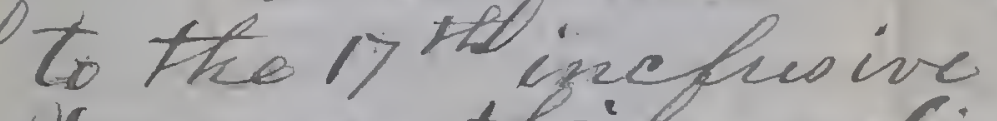
It was a timmy dis cows and wall calculated to cheer the believer and encourage rime on to hector and holier deeds teas in his temple to que his people 
a foretaste of the joys of the heavenly city to which the speaker Do bearetifully alluded in his discourse I covenant anew this clay, to bivepreares to my sod than I have for - forme weeks buck l if pains my feelings tithing that I do on ot progress faster en divine things but a recollection of travel $10^{\text {the }}$ and what the Lord done for me then gladilens mo soul and causes ne to rejoice with for un peak able mas in otto is onegrond strength of efren 
Qhay $24^{\text {th }} 1859$ It larens 6 daus of year since may. Hate entry in this fournal alas alos what changes since that time

sinow evhat heighís of graes have I Ifell lod qrant that Inay sobn regaim what I. have Los in be reinstaded to the fayour of hin whol has dibel that might tive. L I Eveland reorgo. hy 

Omaseo bay cons

I have made no entrie in. this Sairn Sinceprin 24 Ont ince that or formogt of the lime stant but graduel ner ease of grace Andcan surg lo day Praise the Lord forl. the unsorearable qiff even the oift of the the Reristo Lbinmam hreached a tew yeass Demon from Dalip first thinlte to the can inthians $y^{\text {th }}$ chaps $2930 \%$ it huses ingelus ine Bleys the Lond Q my coul 
Quruseo to ny co by

Monclay tue oet2q 1860

I feel the nuesity of Renewing my entries in this dairy almost a Isar has flown since I haze reconciled anything in this Book Bht I commence to night to mans a record of my desires $Y$ determ inations all long to fe free from sin of cloth ed with righteousness as with a garment I have tee nt mourning over Ane a hort cone ines for month es y tones incl for a fresh baptism of the lased spirit I feel that I lam - is is resting in b hist of any 
Leet press upon the kock Oh my recovenly tiathes I renena my conezacent: wifh Pien tobencyht lead me on to ate the fulbnes of redemption

thawhoter unto god who queth us the rectory Herrough our toud feous

$$
\text { Qnused My Mor } 1860
$$

In alempling to conse crale mifself to loud this dan I have fell- the spirt Lelping my infermities onte efforte mi comeing - mith ducees Iflewills thet I sould hoty be andrevere hrays for me 
I an making Some conquests ones self and by the grace ff bod Ithapel bumph ores death jell it the grave of the blessed influences of the spirit

sum a I have felt its Cheesing sans Shining into chr soul to ding Ill sit eat this frit divine It cheer my heart like holy wine And now the hunt is street tome The nt grows on townes the upper tree prise the ford 
Monday tor 1218110 This thas been a day of reace fo my donll in forming new resches thi day o have fell that lsad aproves of zoy course $Q$ h hoh ho seem to gine strength of pamprose and I fugl a blestyde as une ance that I I hall yet come of Biclorions In Bngedilation onfson his Soodnesd t meney how my mind hals heen led crat inzto the deep things of the spirct numer did I have a clequer terce of the fael that the Holly shil inopives a heastithat lints in lood maile in tzreyer the help of the tholy 
One mas manifold Gloriously and toy faith I ma grable gel to draw from the rich treasury of thy storetoug above Q) Lord stifle lead my thoneghto of keep me from falling into error.

Ane praying - spirit breathe She watt hing fo over infract from all encinglament hereat Leal of my mande ing heart

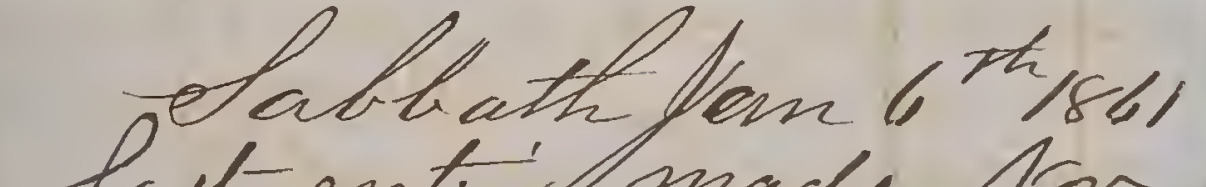
Lastentriel made Non

o' th flog Lord biden Since then And to dan Icon day Praise the Laid atony
foul and all 
fhat ismethm me.

In siting in the twone fligod tolay listening lo Rer But Btinmanz cuscourseing from the mords It ionod that a mane thould troth hoper quielty mailfor the bafucitton of lice Lard Lanzo Mer $2 \%$ mip sonefegoted on the Heanenly minza ab tequnetron the tips of the speakez aceompanisied by

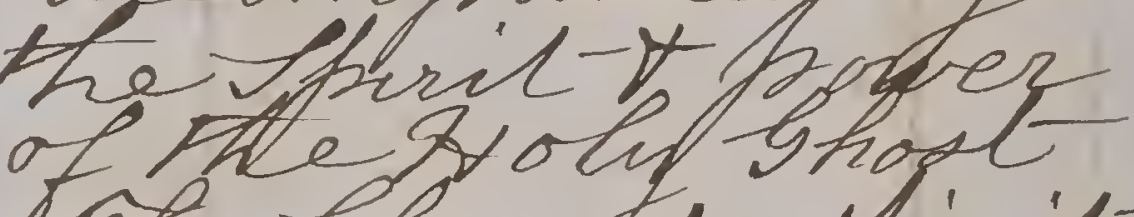
The flessol spizil reguired me to tecar Prenefs to dan lo ony 
Bzetheren y sislers of the power of prace to clearse jagh all din I nhile bquingtevion ozin to this opecel blessing thy pomen 4 preserate of the most Bigh filled the lomple (hies foody) to Its ulmoot cafracilin

Hefreace of Brasch 10 me 858 if seotored The work has been creadual I gannol refer lothe day or. tozir ad ozprobly The proits had beer. in proopels for montts tecusce rift ad the pion ing of a mighty 
ontle of ew decends ufron the easth in a luzizer evenizo slory be to loded I Tghie felt the inman babtiont diceending ufron ms for days With alf the gandtenefos of a leone

sind litwith ale the follinespt $t$ ones of the lodhead zest decure in Ghist

ive is gun reffuge $\checkmark$ Rock off defence A abellybh 
Ellay 26 186

a cablatte

enis has treen a qood dan tomin soul and a loo the fout-meets has been one of progress in divize tife

I hearll the kevelias Fonte

freweh from the 139 Pafm conmeneging at the you If was clearly digmongtrates to my mind that God mas useing the man at Dits Noththiceeg to dfreak hin ongn writh \& Establesh ny. Qmnifresence.

his argumento mere cleas mpraing o conclugine ofefs the Lord I haye had freedon in Christto dow \& renew my ces enayt delemoned fo snom nothing save Etrist 
Thussdar fme27 1861

fince my Last-receord have hade Some of larions sepoons from the presence of the Load in faith I have riew the thromige. Laprd jom Disqahs HeigheMondaly \& Eusdan of this

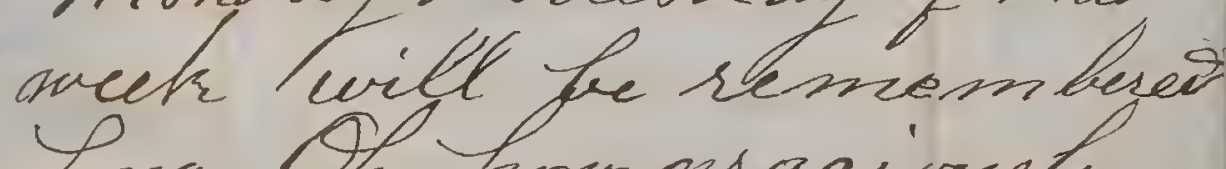
Long Oth how opracionsty Y powerfigle the good Lond trinanlestle ol himoglf to me In fraver before Aim " withe 7 is llord thead out asting Bis diregtition in refference to the infrestion Which has followed me all my life s unas led to open to sodiah $55+10 V \|$ wer And it teem d that it was right in connection with The dubecl undes con Sideralion und Iteleave 
Ais gundeing thirit diree led and affifyed derifaliue lo stiengthen $q$ conform me in mis inferossions of my dutef Oh how I was insede lo refvice in Bism

He fulled me with itis communicuble fulloness is the ertent that. could searelly refrain from of honting Bfis hroimes aloud Ifeel thal mut go formand in Bfis dtrength and sound the qoofel bumpet thougle it showas tee in fucatinets

Qh God renewny Covemant with thee

to kelil the ford ofhm

coul o a le thal is within Ane Rreise Bim 
1861

Deesdar Ene dec 24

Ince mo last-entry

I frimh I can truls say

Hat-I have beef worde ifully trangthened $x$ Esotablishiner in glinime Life I hame clearer sewy of the iseal an As ofing, texosy

His trisam fonzer.

azed all ris blorions

perfecturs

Ifeel the assuranee

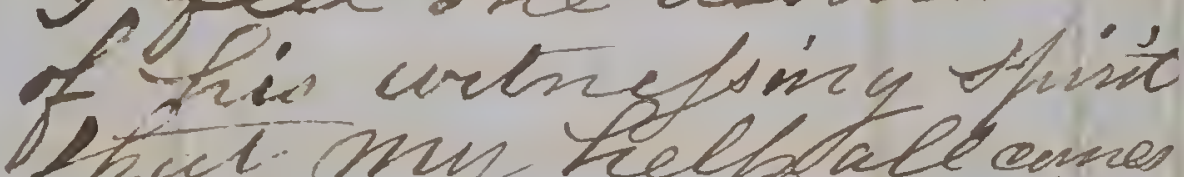
Frove finde of thonoh thise- trone therm

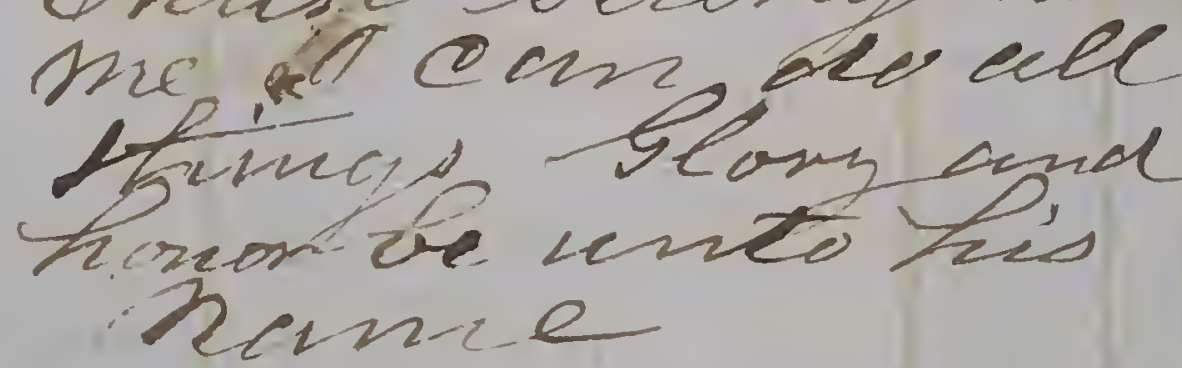


Pillcamoport Sa Aprie 11 My last reeord was made in Qwaseo Cayuga Co hy And Sincelhar tishe livo Sears three montts and peventien days have passed into detrnity And althonghs here not made an Enting these many Anowtho yet - may buth fully record here that I an stiee on my foumey home

Bn the assiglant qrace of Sord at have been Enabled to conbat thus far succeforeully with opposeng influesces and sny chrlestion inleogrely rabbeen manlinies with Some dearee of sutiffyction to misef But minto bou be all the glory for his delir ering orace Thus as a can biulf bay I hane found him 
Lo be a fresent-helfo in every

time of need

I have been afflicted in the Loss of my Son Edmerred lies who way in his leith year But he has only teen Iranoplant ed a little ahead of farther and Mother and another tie is addled to Heaven He is made as were a beacon teat to here us ore to the glory lased Eddie tue are consing

I loo with the shade watt in white. With all thy sarto shall prove The length and def th of bread dits height of Ever lasting Love 
Billiameport Ba fang Having failed to make a see ord of my feelings on the Eleventh of last month of will nowt spent of the impressions mage upon my ntind@as.I belimeby the divine ofoint

I felt it an especial duly incuchbant upon me as a frofessed follower ste Darien to abstain from Labour and food and denote one day in each Hire e hon this to fasting and prayer thereby seeking a gre water conformity to the div inc will That by a use of the means of greece a may be a partaker of his holiness And fur then I also felt I f ho old pledge al lens the leveritgeth part of my 
Ret gains to the Loyd at the ind of cart year it the disposal of which I expect to dislivibute to bercesutent objects as the Lord may dike

decking his counsel to guide me aright in its disposal I soleshmly de clare in his fear and lowe that I will honestly perform the above duties bo the culinost of in y ability God being my telfer Ar of. Enelandp For the Earth is the Lords and the fullness thereof the world and they that dwell therein. fesalims 24.I 
report Sa

April 291865

I am huffy to be ar testimony to day, that os an slice pursuing the heavenly way tut If eel often that - the pirogues is slow angle there is nothing good within one

I am busting in tim who is my deficiency inge can inly say Lord help me Ever to realize min weak occas 
Thursday lune, st 1865 Th i day is being observed as a day of humiliation of. tragus in a ceordanes with The proclamation of Resident Stimson issued A piet 19: 1865 this day of public humiliation was recominendeck by the for ed in consequence of the assassin aten of our god president Ardonan Stincotos on the night of april 14 1865 By this colvardly aet a nation eras made to mow the loss of ce great

and doubtless tels services through ty Years of bloody war will be appreciated and nemsentered by all posterity umosonger 
good as it couth the upright in heart And now the most important suggestion tret presents itself to my mind at this moments is of Lond what can I do to advance the interest of thy pares union the couth that thy marne tray be horae among the - ziliben of man try presence oh ford uni manifest this clay whole meeting with may class cine. bit ing to tipenage say duly in try fear Bute ind bod be ate the frise scum and formesmone Cement CeTRubroust 
Lonefoort a

1865

Saturday Everaw Yedy 15

Tight before last and yeste.

Loy was a nught \& lay of.

epent afflection and Ties

nrat enounaling

tlike in my pain I Frought

it the most sivere of had ever

etperienced

But Hen pawe cornfort in ufliftic was also mine 2 and bon 4 th $1 y^{\text {nor }}$

For nur light iffecetionoutiol

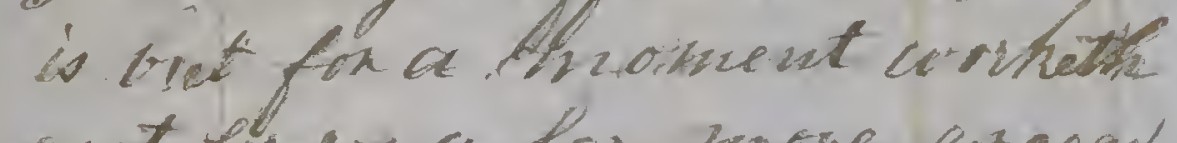
out for u far mone exceed ingor eternac uright of blosy

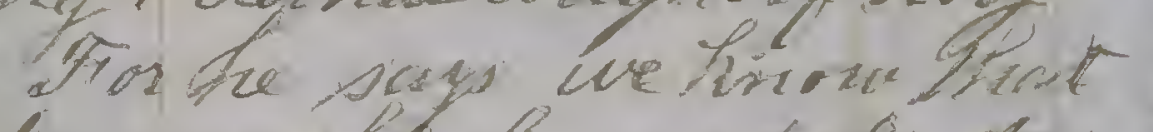
if curcartily trence of this tabe evariefe corere dinotic d cue trave a fincling of bod an tewe

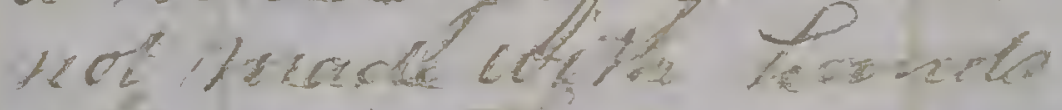

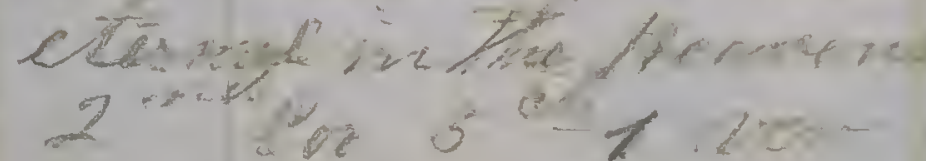


This enening my thind is Cloar

Oze leghat shina

Sie curtines of the spinit afforde me eneat consolgotions utinal a fele more thisen ever thitl wle frial 9 ane 4 all pard I eaze he aned do

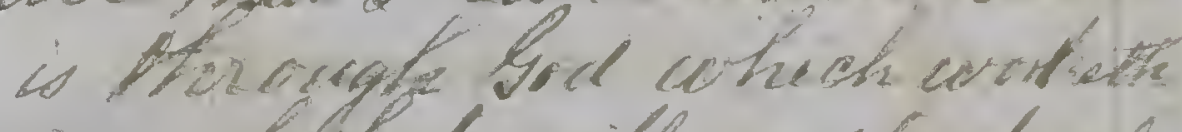
wic us both lo will arat lo do of his good heasure

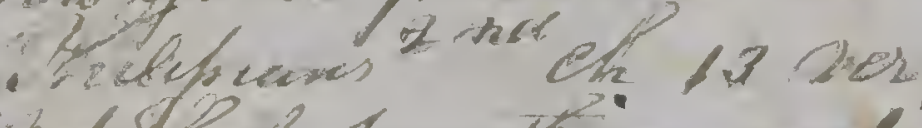
chilud ofred smathing as clid tire molnziof when the ganc ifor in thee Yiowe I reme thisough a tove and buy ring bod twain certhed baef ce cunte

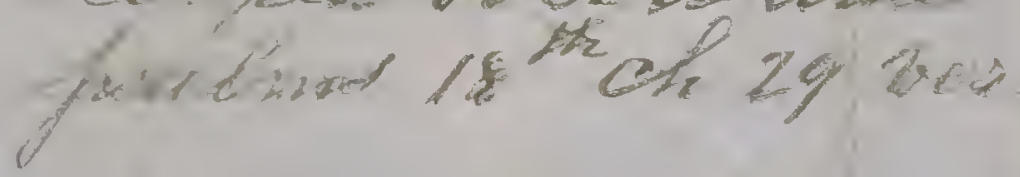


1865

Umisfort sa quly 25 $\checkmark$ arose from ted at a qucouter to fine and rowed before the lord to ronder thants for tis. zizercies my sart of filled with grectiliede to - od for til go oclmes Ina I ful tiue ecuon -lay I live I beforze incler greater obligution to finch coho is Stee creat cuthos of mutreins. thre inform itles of the body dhioh of fech bory plainly this orhorming adrnomish me thal the seeds gt mortaldy aresown urtiln me and that tinze $>$ discase are doing their levols Bect fou all this Prade the fovd $4,7,5$ 


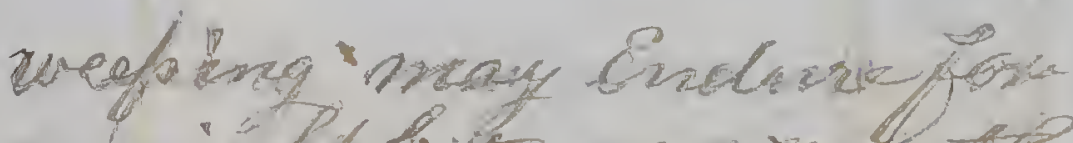

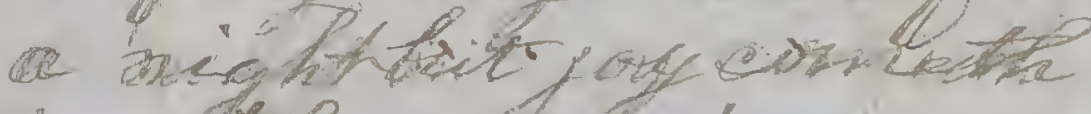

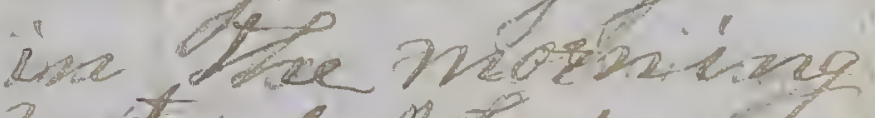

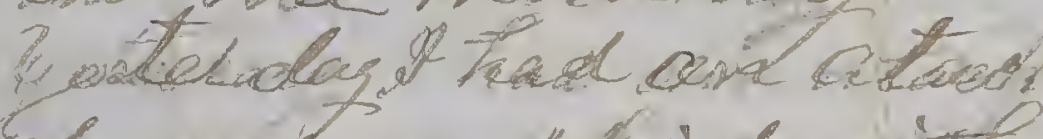
of mere ove phainen weith

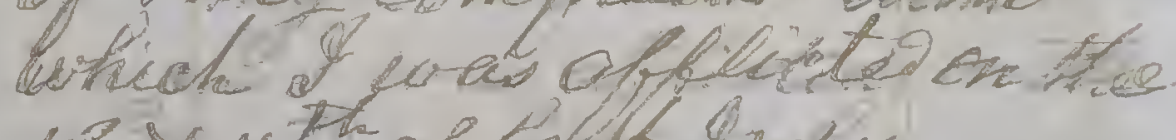

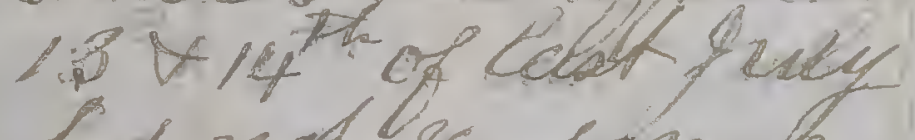
tost nook lis sewerk

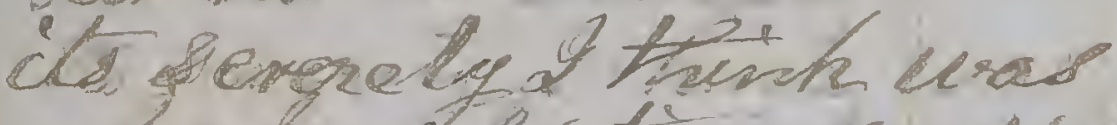

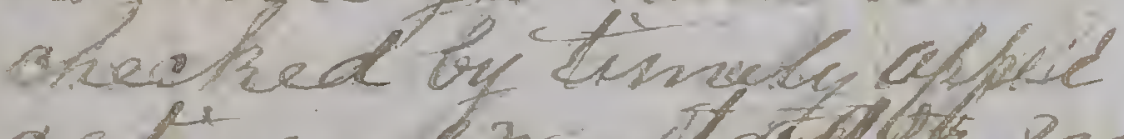
cation of mostouter nes sisk by the fresing of sod aried other muint used "feel to dourthoch of tiale hoon shocower from the atach of this diseare

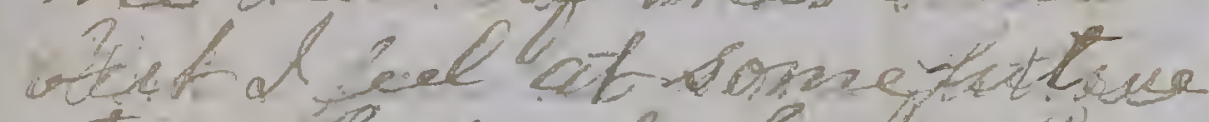

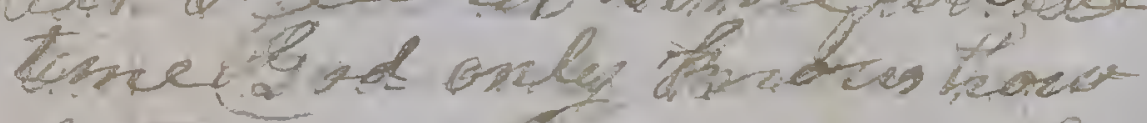

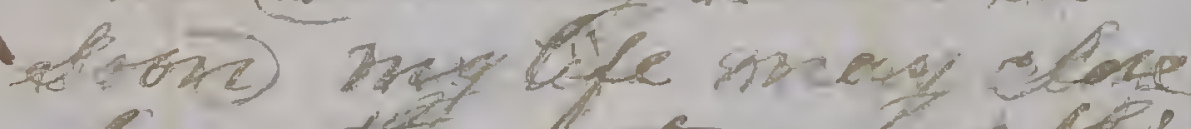

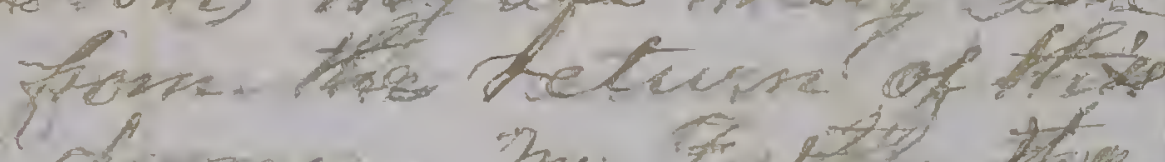

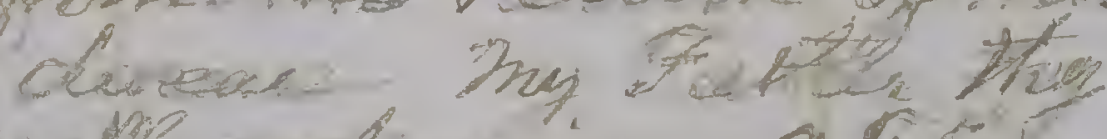
bille unt mine $a_{4}$ 
Meileornopent th

Mronday Eve tow $26^{\text {the }} 1866$ This hasbeen a dow of great reace at is on Irefocise' to the mest in 8 church and met manny of lods peofle who were cinestly deefing full redenftion triouch the atoneing. bleod of the deeir rectem er many in the last Ho wrehs have beens incle led to testify to the to ower - blooll dirine to cleanse Trom all Sin

and the evorh is stiete jrogresting

ondy the Lat multifily the witnesus and sheed thern on the uag to alory tै I 8 
Apr Wituamsport Pa

13 while looking into my dairy his day feet that os howls de ar kan of the long inlervoub beliveen my records and al now by the grace of yod will be more triltyule in recon ding the dealing of then wii my soul To day my peace is tire wriverland the will of hod is my will Grind to oe lt re Hins y have this spörit and to be a f will ties of the divine nature is the once desire of mw A.C. Portland 
1867 Sabath mom hray 12 th it is coith rearlfet- Hrarns a recond the arodrues of God to mupetf aridale mannind All is well tis nusuing Hire is not-a clruch to unise the been-r of lods u'r tounder peace of love vicid cubroad in my soul \& Fin riva I hans a hignes a acialion of the mrecions wes of thispeligion tran ivur befone Pcrely the paln of the pust is cestes stimeing liqut final vineeth fon one and inore urito the perfect day horeorymaine $x$ dorminioth the cento Gocer the Zamb Poveres $r$ a 8 


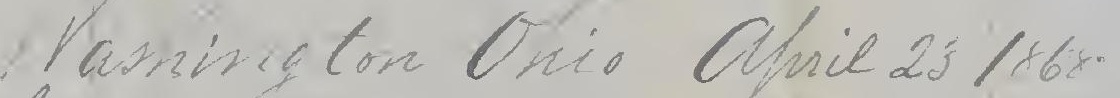
Almost a livelue month sinced have made record A qlunce at

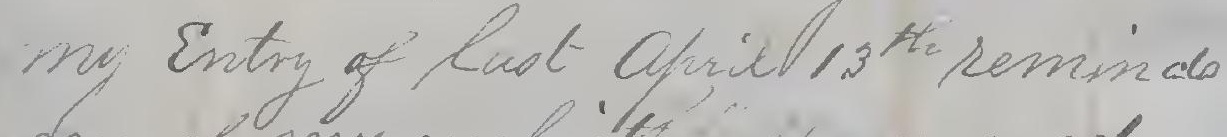
hre of my unfaitrif. itruess and how easily res sutions o vous ari - vrgotten But I this moming cagain renew the covereant ans clesere to press on towwds the frize of tiw main fory hign a prebions infunersce resto screrlly

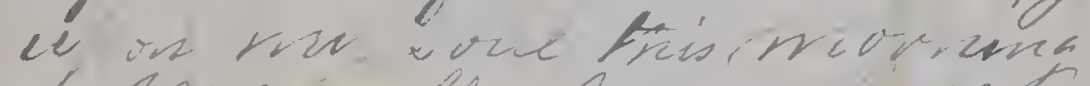
All is well. I awe the Linds cund the is mine a ciner y aved by arnee. Slory l am now camousing his pluce

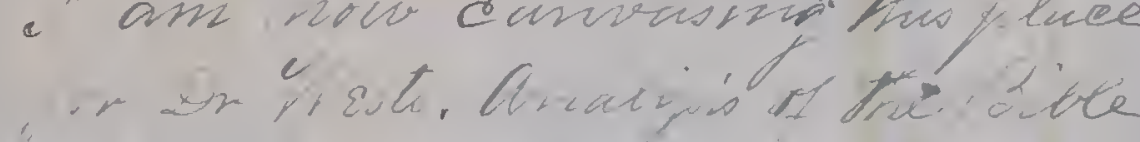

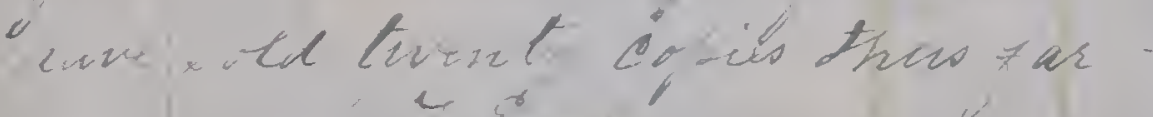

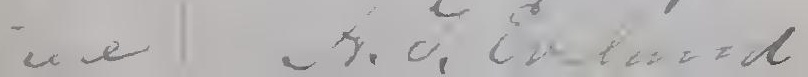


Ulondar Cprie 2y the 1868

Lad Saturda evers a dan of creat

spercluacets and poiver.

Trule it weornd to me fral I

thud a fordarle of. The lift lo

comze. Ch fercions savious

tringitr Thee for tire communcalio of trey ice irit lo the inward mui, even "while here below. And eselirdur, the C toritians stabivitus what a dar of peaces ardet trust I lisloned with much in tesest to a vermon ditives bo zev Seonas Carporter from

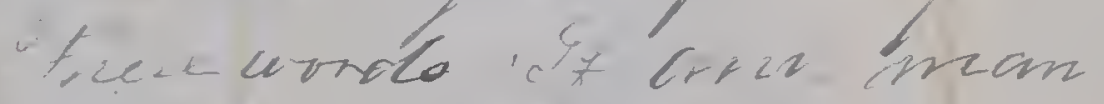
preask ans othen a os icel te

he is a canded arod znan kind teis words" carly fonce cuith

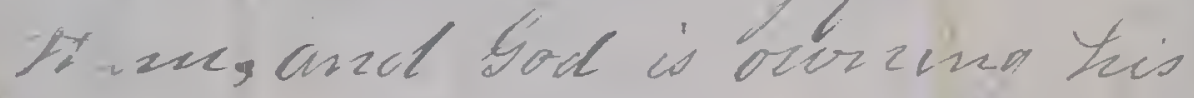
Catrose.

rowhing ton $C-\approx y \varepsilon$ 
Cfintiretor vnaw 241868 Sabbelth $10^{2}$ a 12

I tavefust selürned from a delightfue clus. snceting to muboard ina nomel with iffors Sorah bundessum an ages Lady who is an estimabie Presbeteriani Ohriatiun ard Ezen frlang in Lije and In Alico house of have been at home

religions dutie are first in onder here arrd citis things suvervind to them

I now ans encubled to insube a recond of great muen on srul and bifilaing linest in the avacise. merits

$a=$ the cutherwor y, 


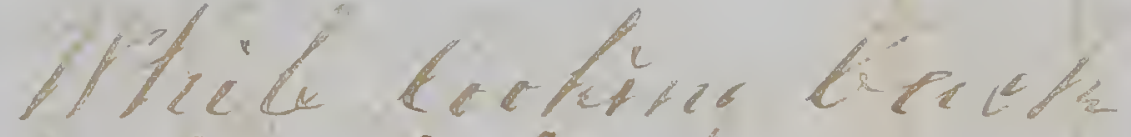
I tra derle loy me

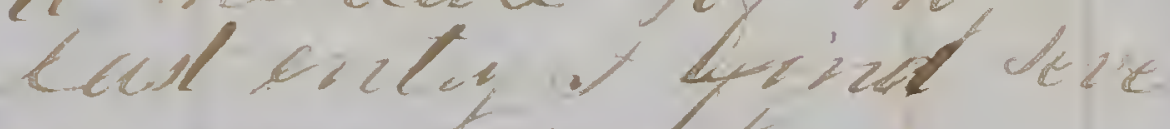

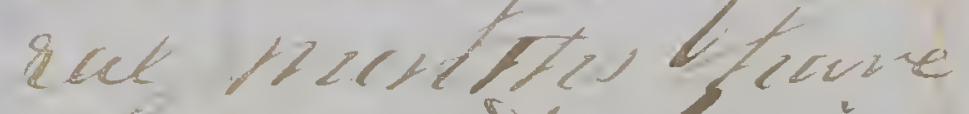

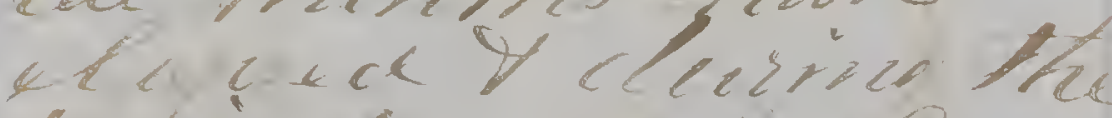

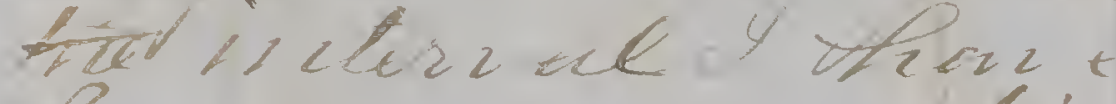

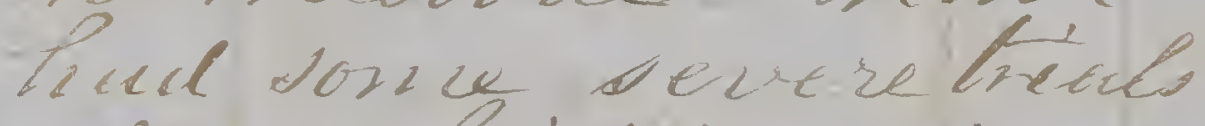

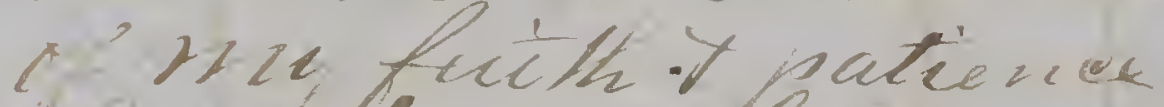

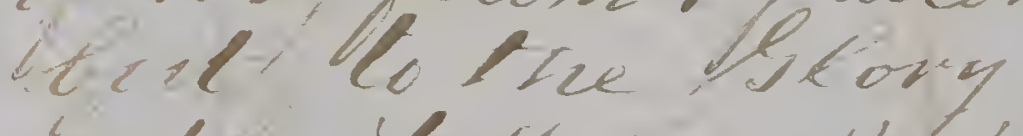

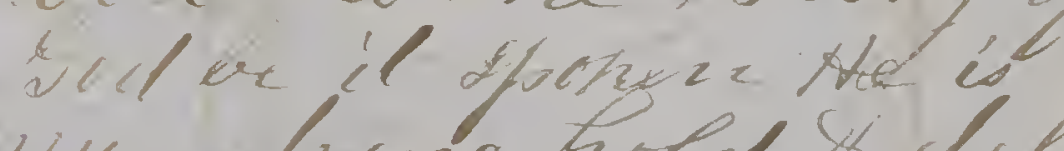
will horig hold \& clelis lear litide reop feet

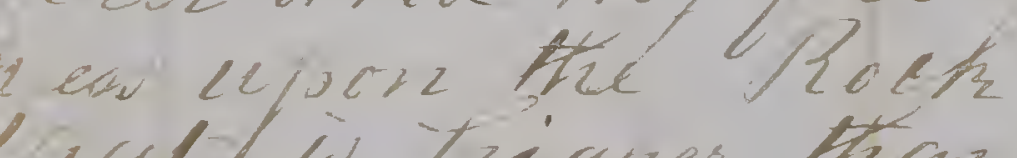
licel is tiquper Hicar t iter reace to diu

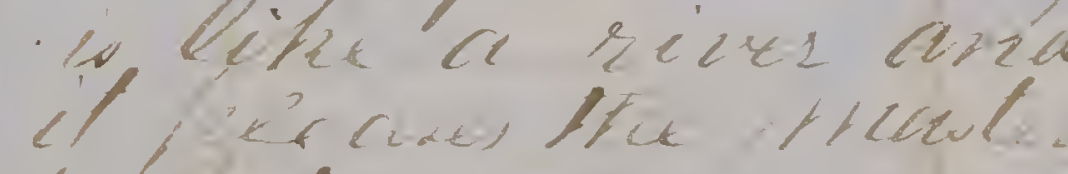

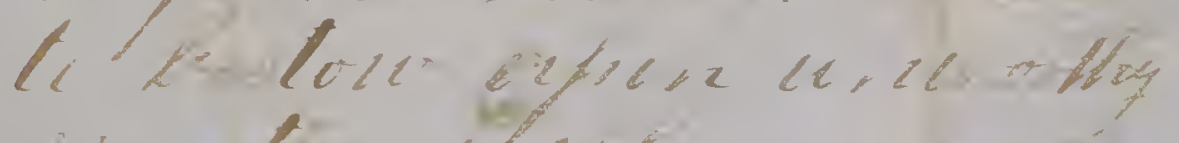

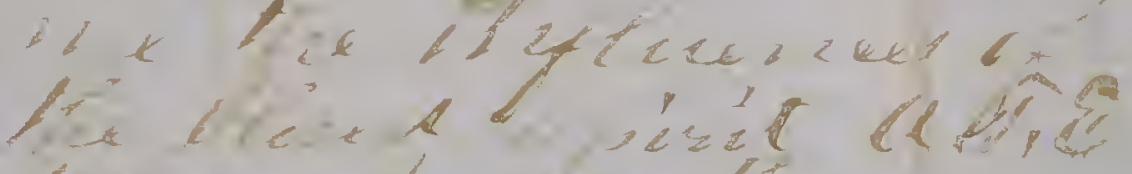

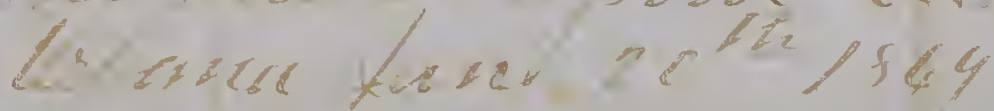




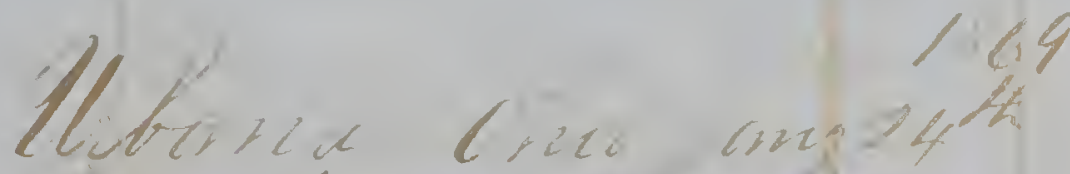

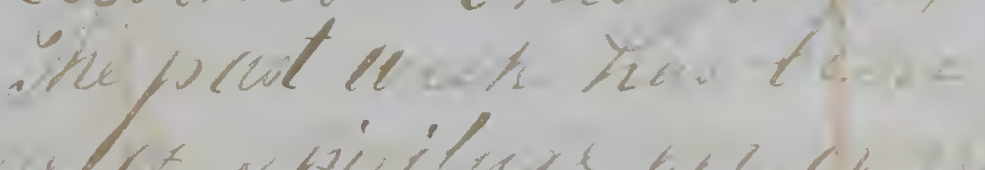

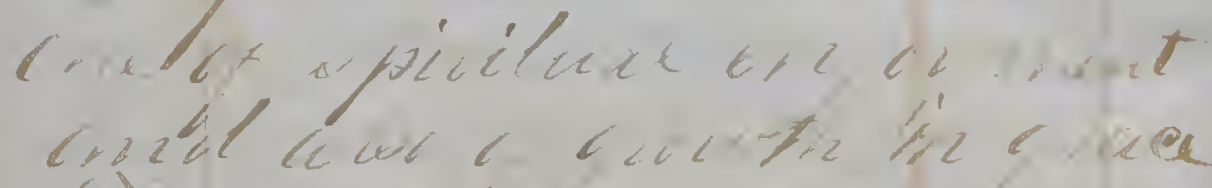

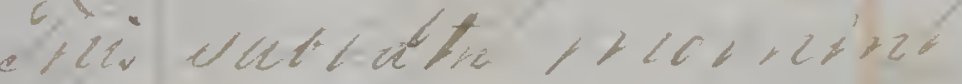

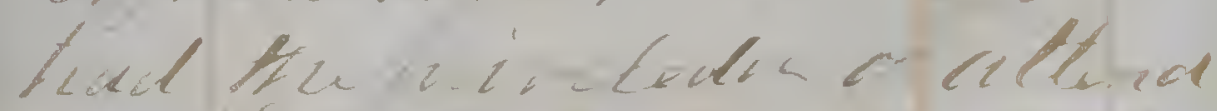
ine Lové fecesl al whe

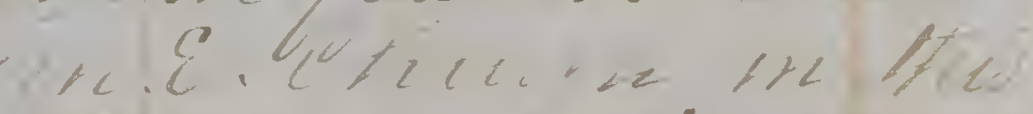

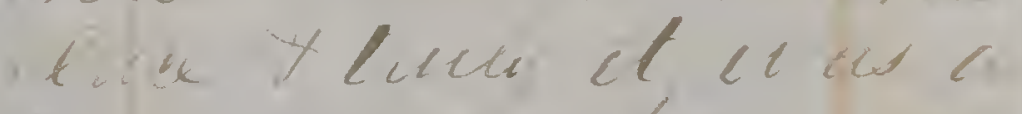

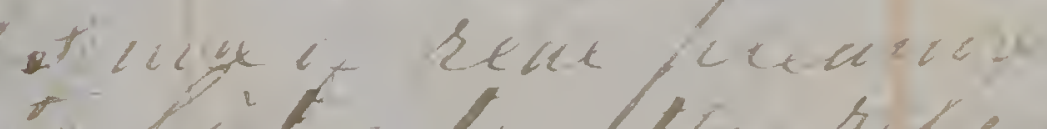

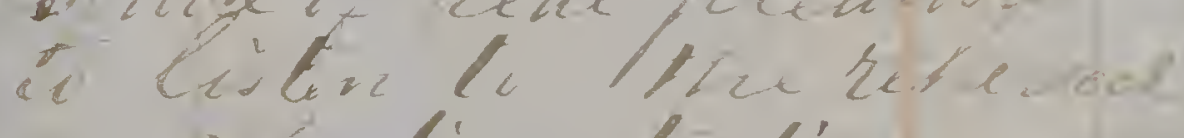
- Míulian leslin "अid it क है

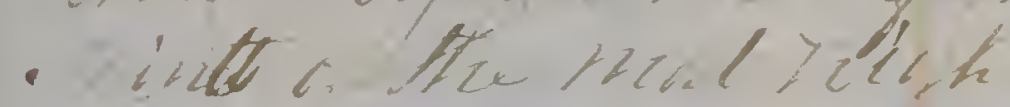

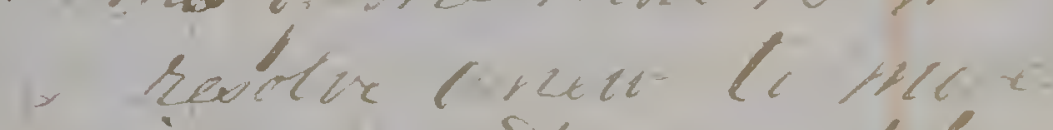

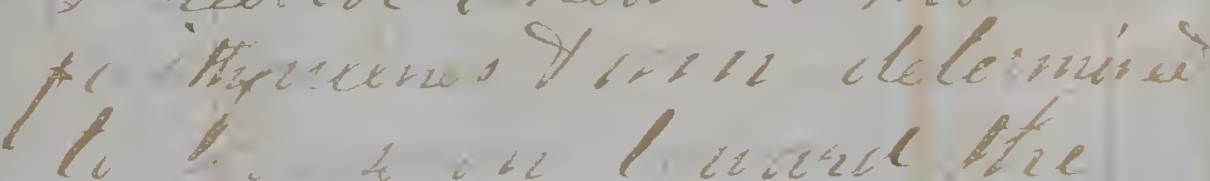
Io b. a ou liand Afie

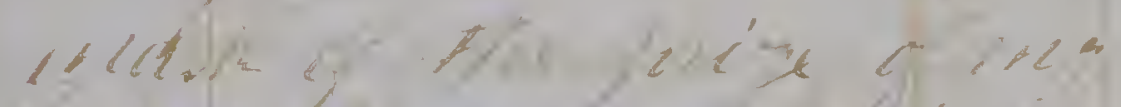

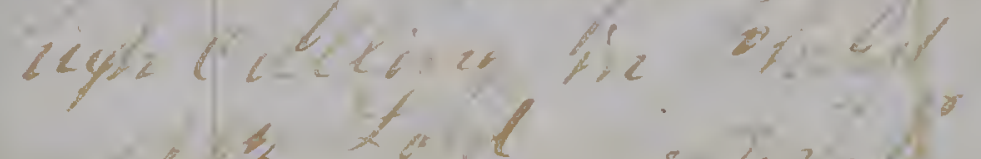


atit $^{n-1} 1869$

Alifina Chie

Puncie the tood is the kencuage of we recult this rocisuline

fo exw theteta b.... wiaced duis movning ing weter croctind tive

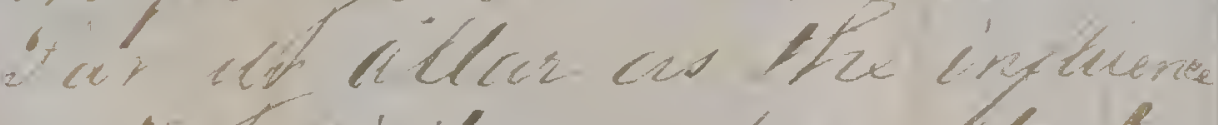

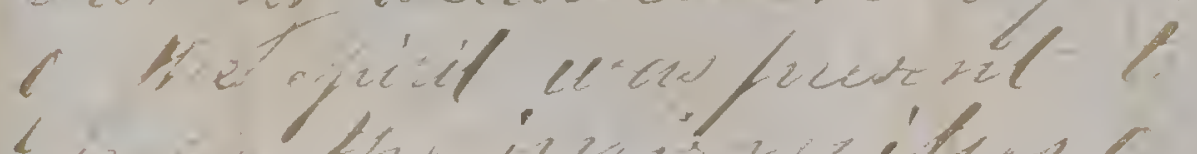
in the ine zalews

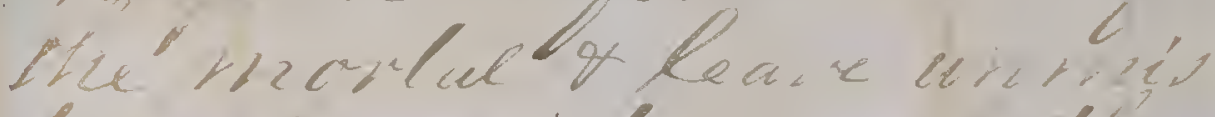

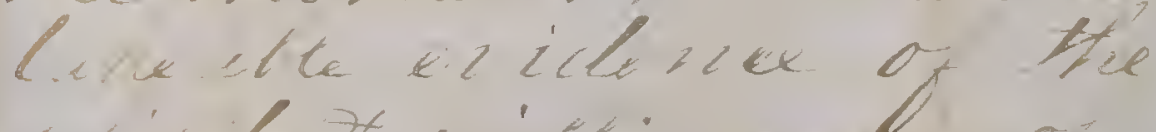

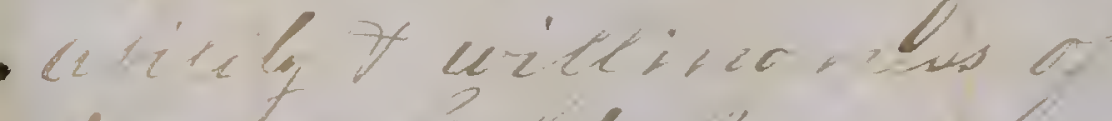

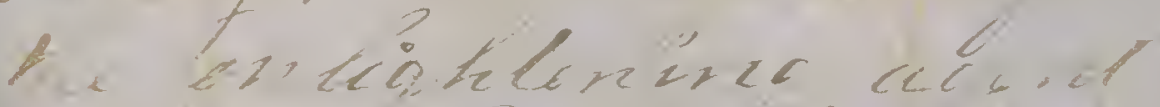

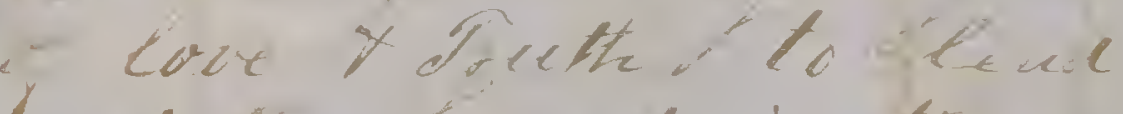

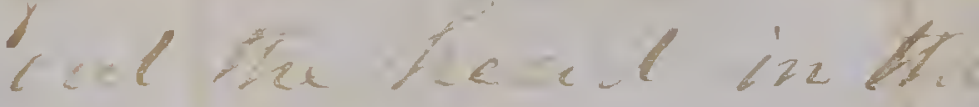
cy it if lace un. ix 
Yeude ted $9^{\text {tir }} / 044$

S) ilide the Lord for the

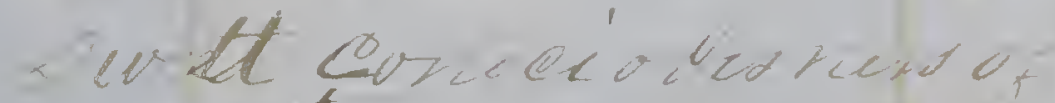
acce lor oce fire meming.

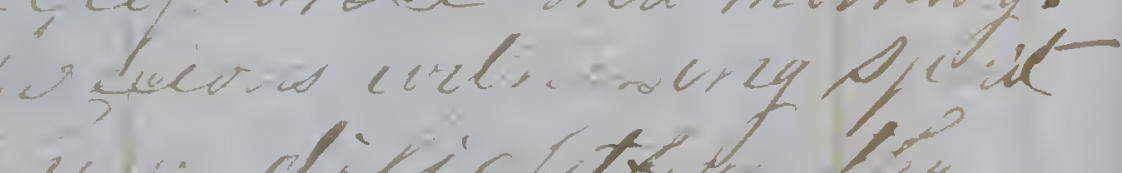
bolimzonet dity

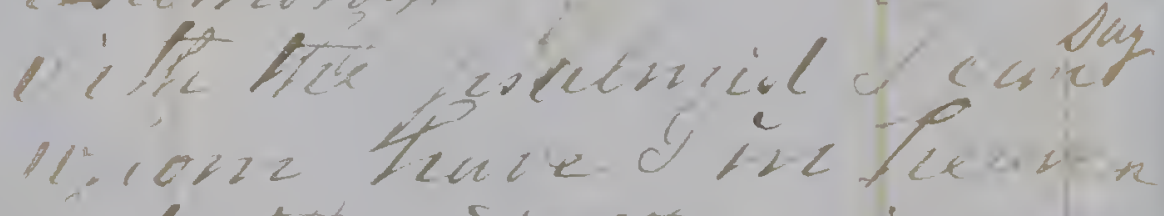
-11l thee Y Preve ì mone

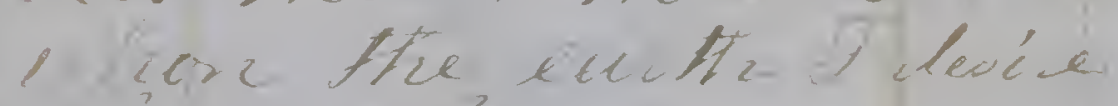
coisle Mres

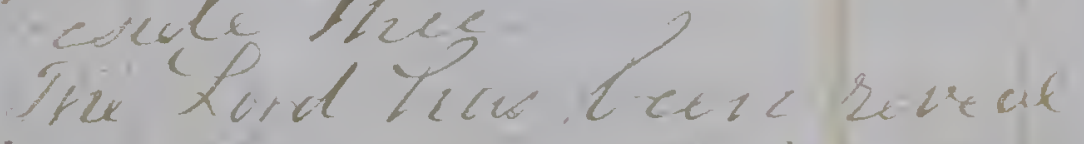
ing triz.wety choriende to

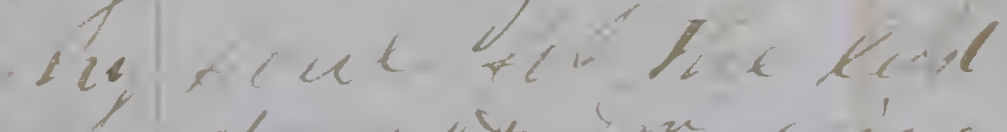

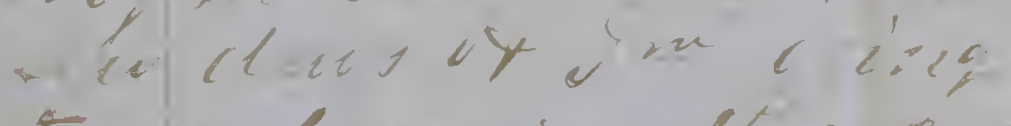

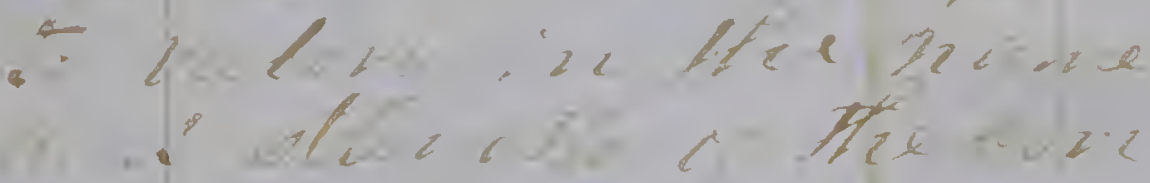




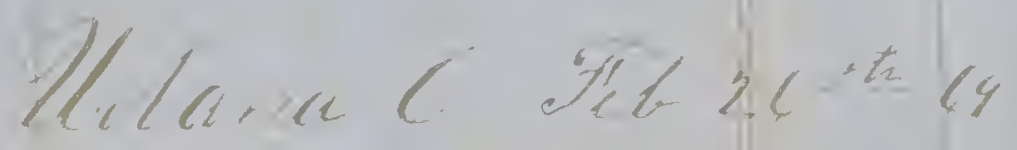

"Hiliel

- Xitis

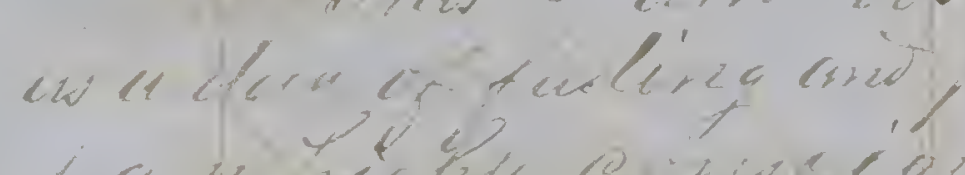

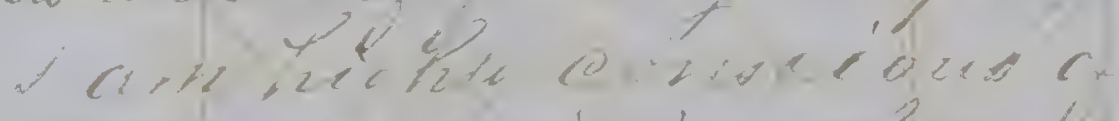

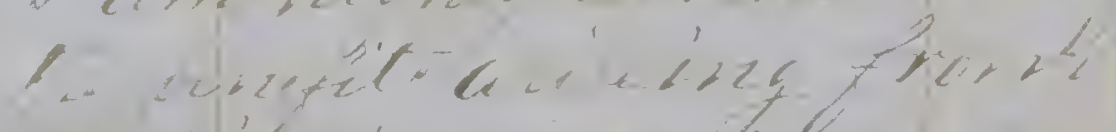

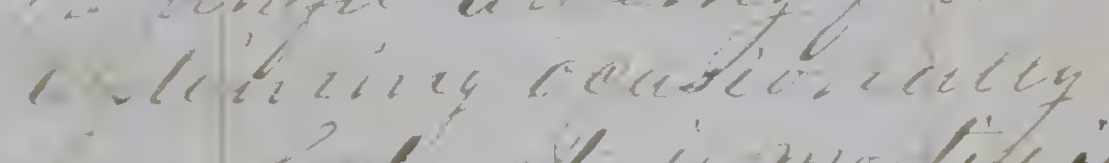

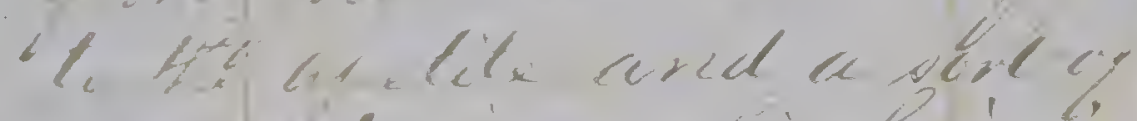

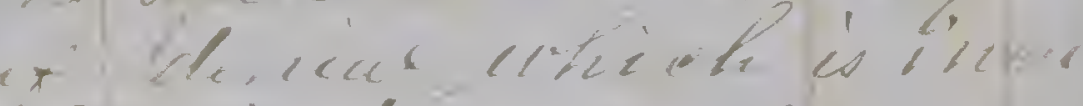

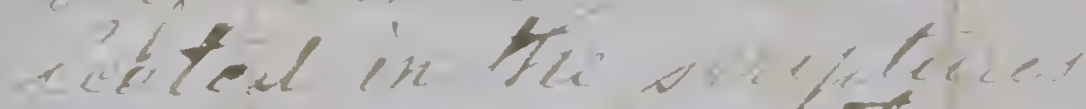

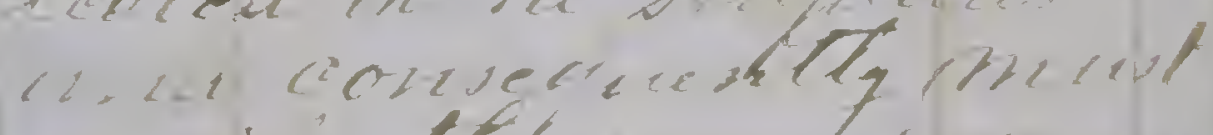

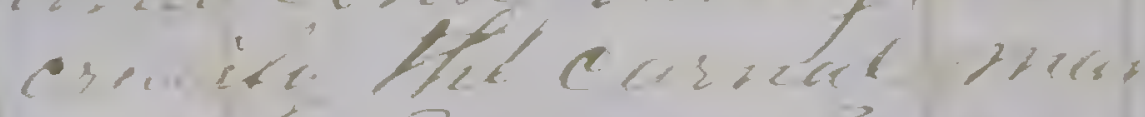

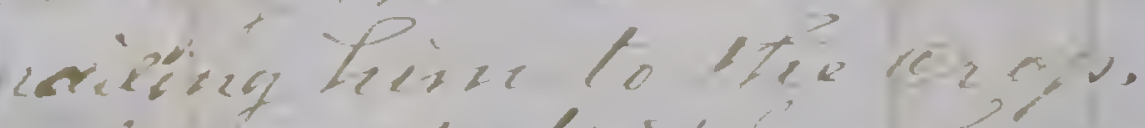

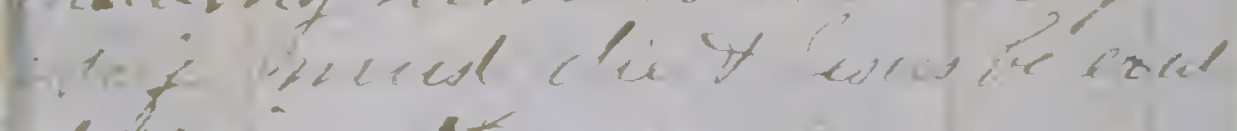

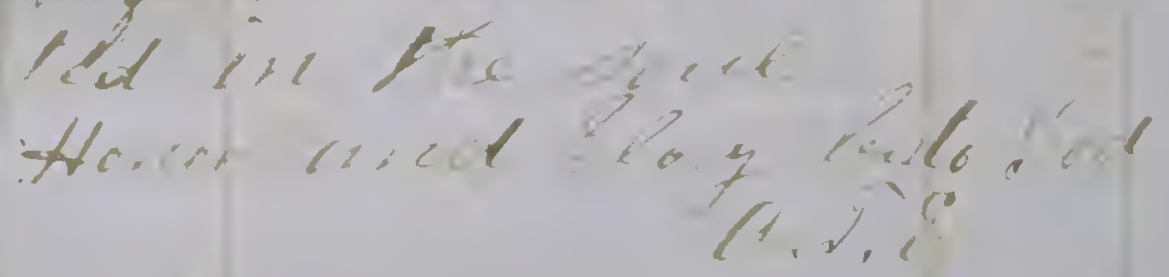


Woid mich

1870
Aflehis
S luave

Hown much I have

neglecled to pratse

roular in tries in

Ats fonmene bue nut - cenve d a tach no

infeontazee too

it for I belive

it to be a mems

of graer xaloo a

sstem of doing.

govd Ho geting Goud To day.

reop mi reppine foreser thine 
The Swed flow of fuace ¿o Mny Abul ithis Mon ming firousfet me to take on fion s make a kec ord of the fach Geslerday tuns bire sab toutti ox also a day jincal fireace Y iftesd-

But a dar of qreal trial of ming tith in the grace the Lord losug sthall rememon -1 to all Elésnily Hizmont tis oblace riushifined Aforivisly Irave a sysenfiathetce friend. ovid Asle 29 
Puid mich mar 4

This nus been a duy

of calmozels and

Orest in Lesus

My hearl-tras been

wetor much bifled

uftion forayer to

S liave a deved-

assurance Gf necep

lagies with the

belozed Any tile

is clear lo thal

treavents in heritano

whiche facleth por

acray

Praise the Lond

it pry doul

A. I, Gueland 
Ooid trich

Anar $16^{\text {thyo }}$

Loyous foy ons S sace tsace

the lum of provive

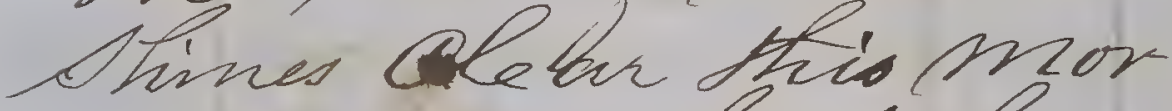
ruing cepor sod" hean cater curth Pull blory loe lo tis prasze the lare of ientiteons nets stivis whoth so Lefo Olearniss is my poon sore

my way is onuard ande ufuturoud

Q.N. 
Bicl afor 260

- Feal this Sening irust is inz Seaces and yel Id ane. oenditle of min in leld to enide oeff bery tracele bull stel I arm kooking and exfinco tron Vthane faifh to telieve fhad I straen libir infou greater But bleks his name Fonewhat I do
Goves I \& 


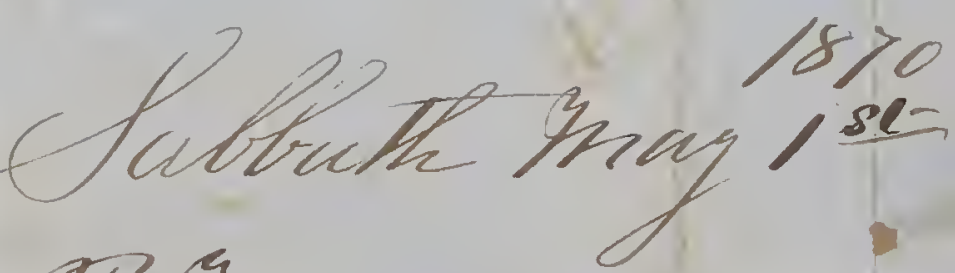

4 I In

art thave fust crose from beconel the Lond in seorlel. husur uscel bo fourtel have trud Acpolfs in andery Exiecial haver douls fict that the is a frager trewring and a frager lases wering God a roter of de fende inel sthong tower

At. $={ }^{\circ}$ 
Gid fuly $1 y^{\text {te }}$

Glown be to fod

In thel peace have in blieneing in feons Puy tonfidofneleV tongt in the Mnights orowh increated ch have fud in and geeers to a Dtrone freanon ty une in bearing

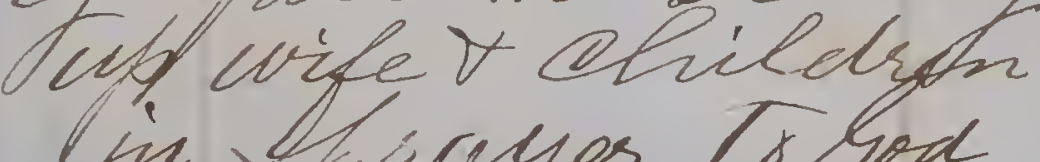
in Wiriyer $\mathrm{Co}$ lod thal the sonight restone his Gurons L" some t fizing Fhess it a Tinforidedise of their sinfullinars * tren fonileion and adofettrem is itis $u_{.} \tau_{0} E$ 
bid anuary

on loond que me a Lestinnonf on this vrecions Skive Ycass orze flimg ot facl it day azzd tfztet is weth the isalingla cience day

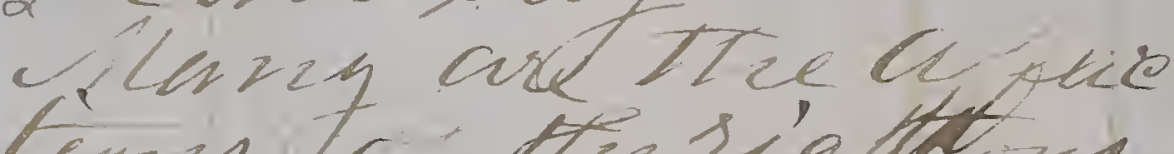

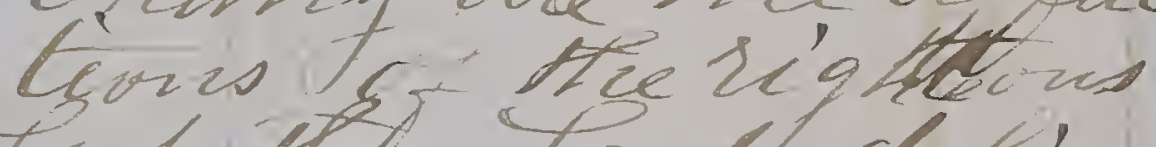
trut Hite, tond clelinen

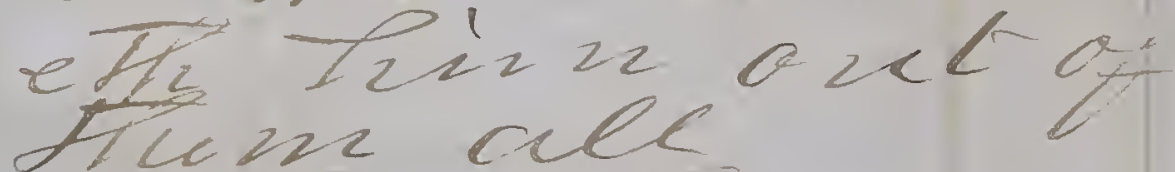
Jame culk At is turnd Yus been. Luid Yreanile eysor

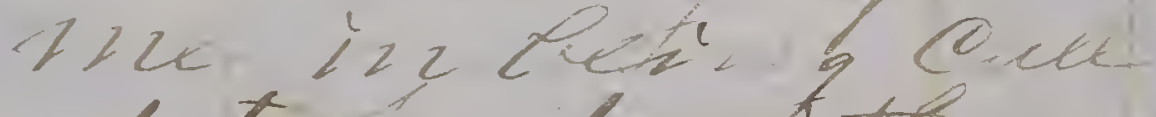
ed to jant weth mey clens Sibtie

- Ptre died inz 
Lord Lkec $19^{\text {the }}$ and resto freace witly in fesule

dear ofir I trofe 20 tuie tiry funx pinat in tistall tiest

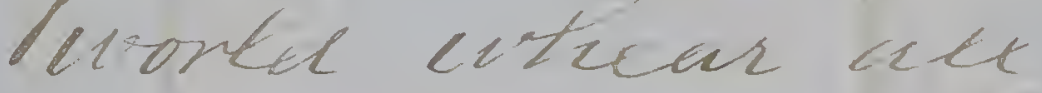

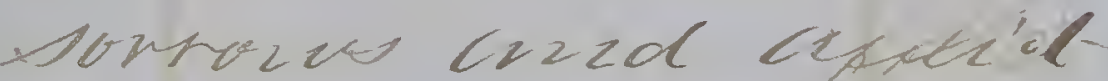
ízu cure ber

When though fiery tries

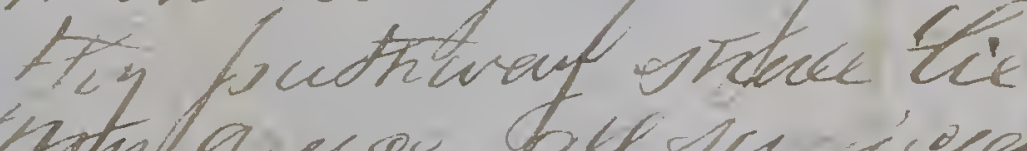

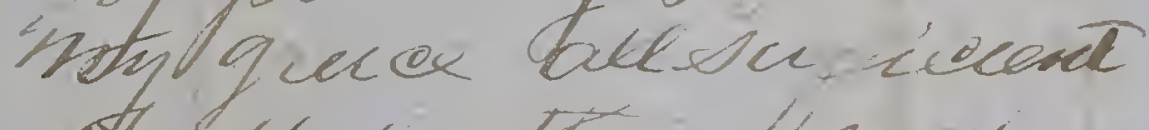

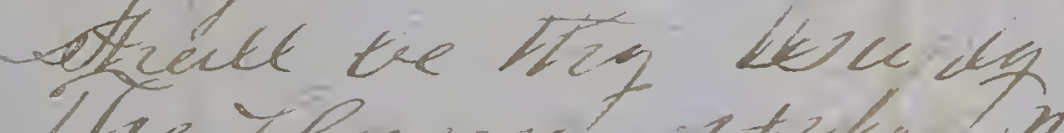
The Ylenrut ytrow het

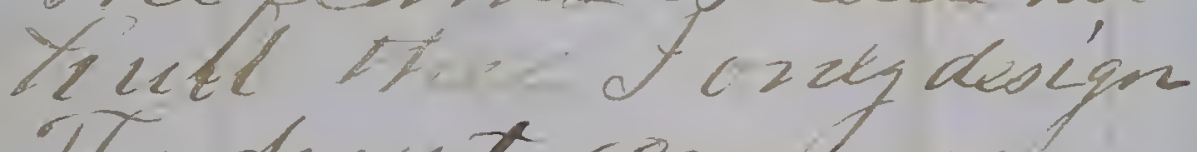
'Thy dross to coonshunes Hbin qutol to nepinue The Latal oive in $12=2 \mathrm{~d}$ He Lond taketh iswory

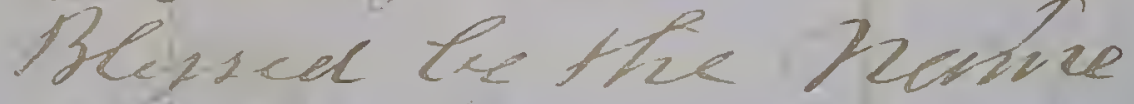
Cot the thad tromeres 
Dableuth fan of 1871

I an reating to day.

Ot2 Yrow sucetty

restirn ine feocto

Tisio is acliesl tirk

enrequmerate in reunt

incula tecthing op

The desire of ang reast

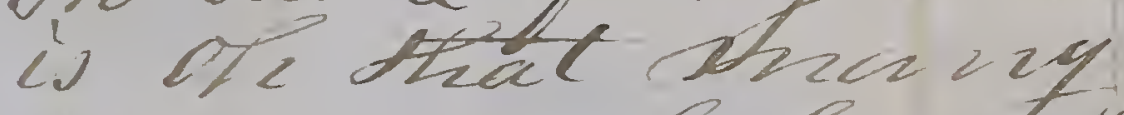

mun sown te inowertit

to ta Irafy Eafuribude

ox Amis freclown seot

ine polat ween tie

trist of the new

Hent Leerz ozre lot

religuves entarlignent

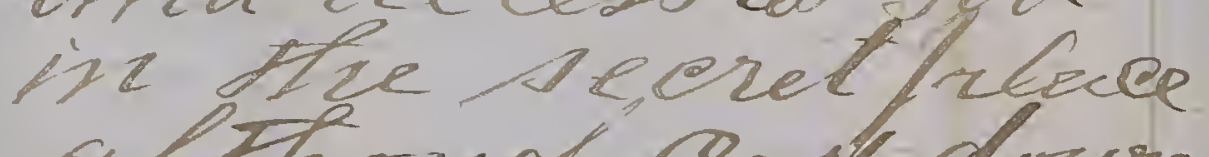

al tho ougte Cad down 
cet tisuces cutrike Hisuting of hey dear onse ewtid so

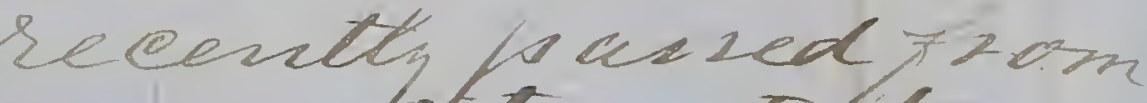
in - a quget liventy livoefet of 7220 afinz ret cas one travizag, no tzopue tuct rep oidein

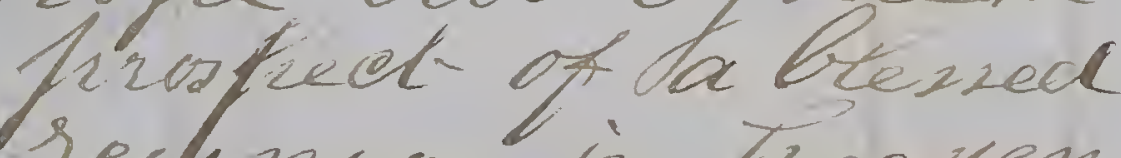
zechnuon, in Theauen Strave read lecesolo sod is / 2 raqus the fost wher h whice Lolding lear Hruned up to flad fion Their \& vaveloione

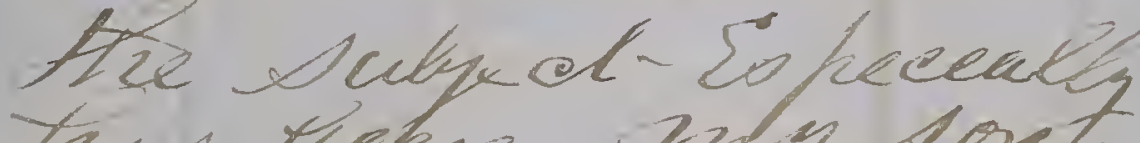
Yrad theler izuly gont

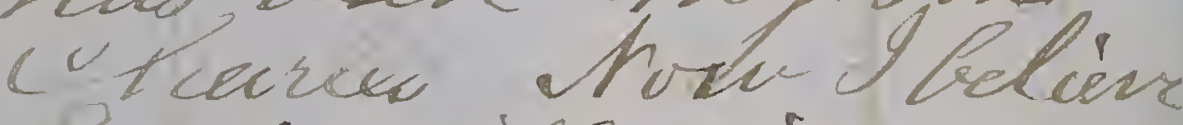
- or vill gine pue The clenibe of my 
Astroit ellich

$$
\tan 1 y^{2} 1852
$$

Unim lerval of Becuen 4 easos Y riluc dup tiós Eloppecd. al onade ar Euto en This diang -ithure is dure ly a pevisoz this A Aw Shall creount for this truth tully alas bi a tholl for a lack of yital 'elt linowe Yeen regreetyculet in lishowe 4 avour recondircol at Phover intar ma L Itea rect olvte of the mirsh ansed-Gfi-ill 
Fut gr of that 2 Rad begun ló claratir tie peality of a

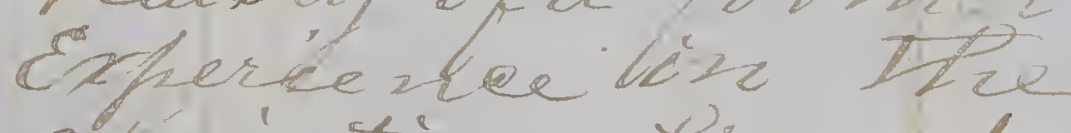
ctrsictian tife hery zerils fict altirategh colth at times of nemer have ov naver can fongetive firat lose ontiz otther cuondo bry first a cloption as a don inlo the family of socls dear llicilren al qives mre areat Connf ouh and. Wreeh "ulipfaclion Hicut. Lo trullo helieve Fierh Ptrie is a

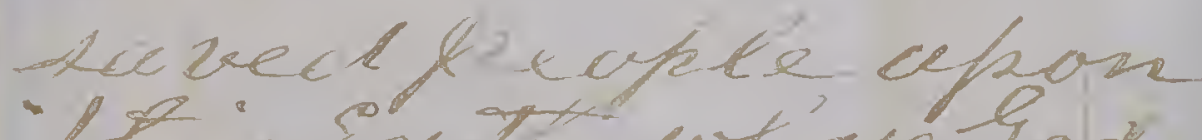
- Itic car th whase lod

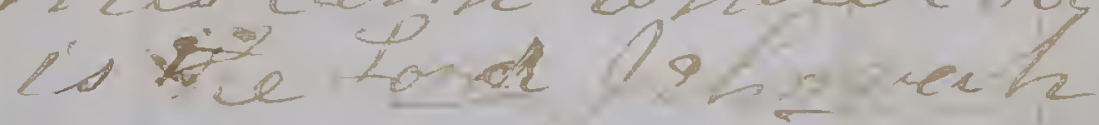


ard ther core

Atis blood loraw, le ell

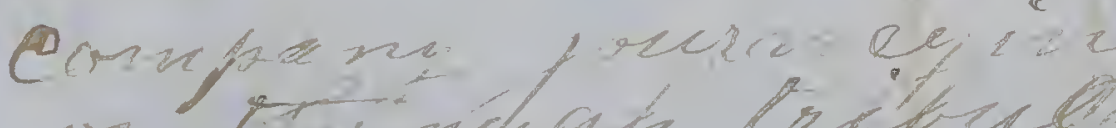

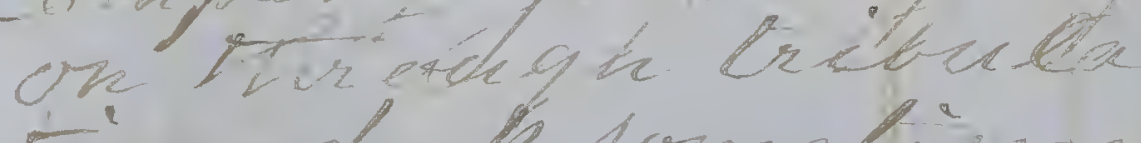

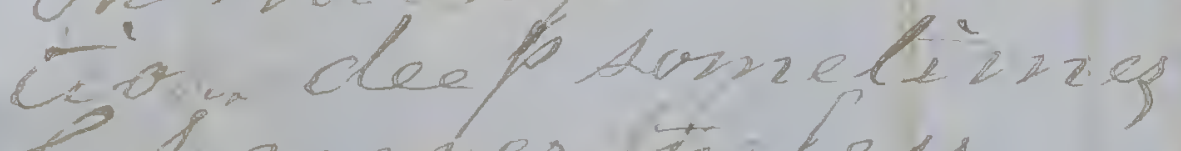

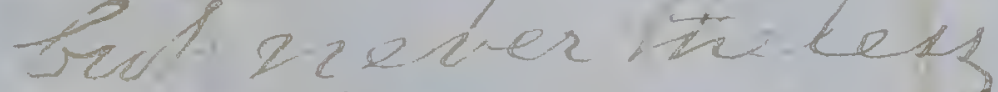

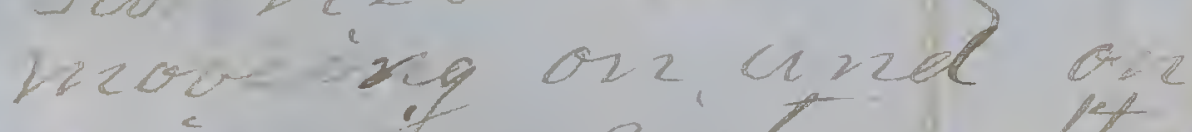
qainuziq vichang ofter 2yelave $\mathrm{Ci}$ und tifit Pinat tivere our Ftre

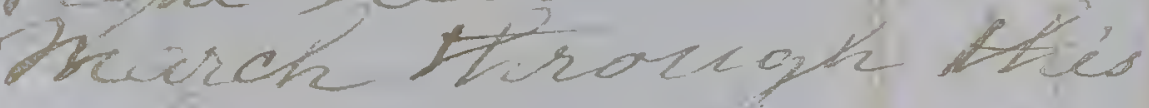
race of hovtores as t tee lyad chlorg prazuz day to dato Aapt. is Ihahyieate colcuse god is the Litrd

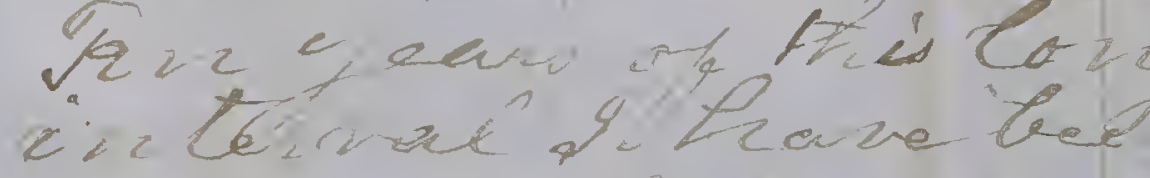
den ixi-w atiel coned scile a ketporen

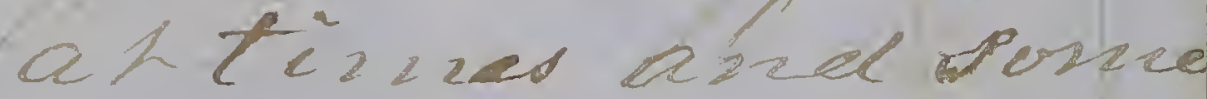


líz'cos we

Reri Rear Itie crid

oft the forerney

bewi pever fioturation

row have ll any fears

Hial otralk toe as

kown ad of licuetine

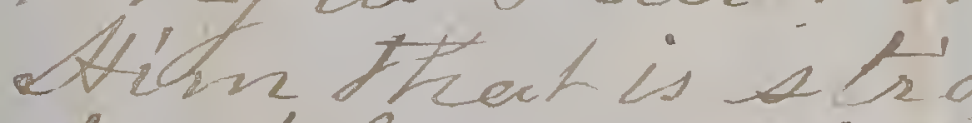

to délivert suightef

"l thave trad a cruse

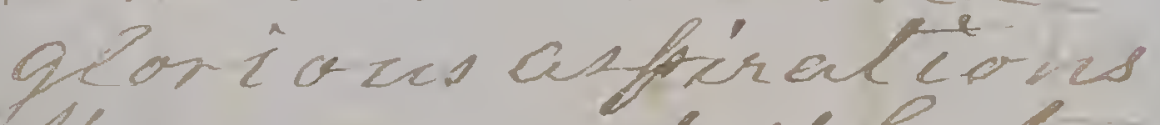

Ateavenumand of lach

choed yesterdac/ weres

a derz of qloistres?

$x$ théce the trelleveing

izz tescus

The olel mutto is the

pacsumed lo olay

cieer ozruard anel

upleces d

$\angle 2, \%$ 
Wit $=$ ais

$\operatorname{fan} 2.4 .82$

This is a clay of qreat liecot and Aceckicaly

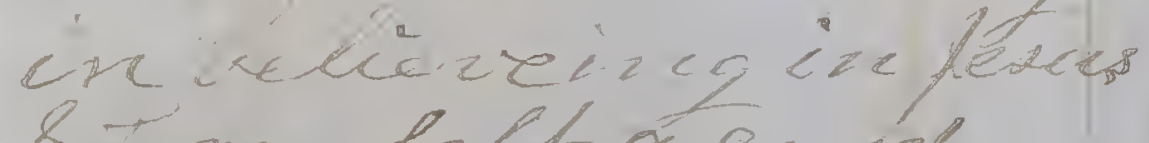
al -rame felt ox ond olezree of the inspinatis of re dopirih Q a bres kerifly ing. The Deciarnacion of ize Treak lisioxtle éfeekl when the sags in revn

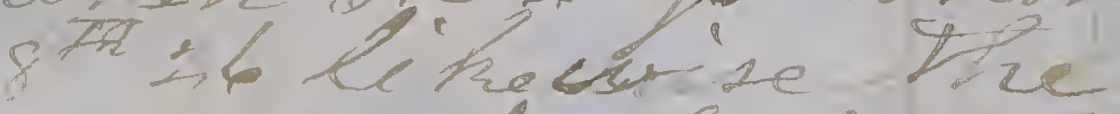

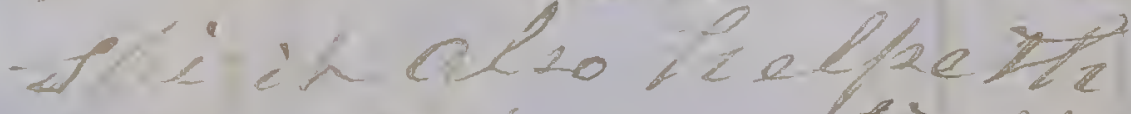

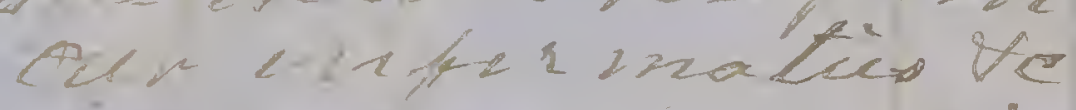

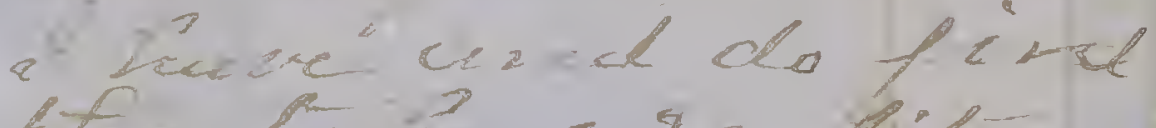
ftes lo ine a vealily

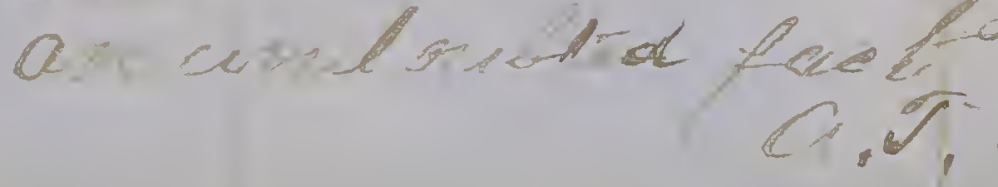




$\varepsilon_{2}$

b harkso 





$$
\begin{aligned}
& \text { Qemutur Qurs }
\end{aligned}
$$

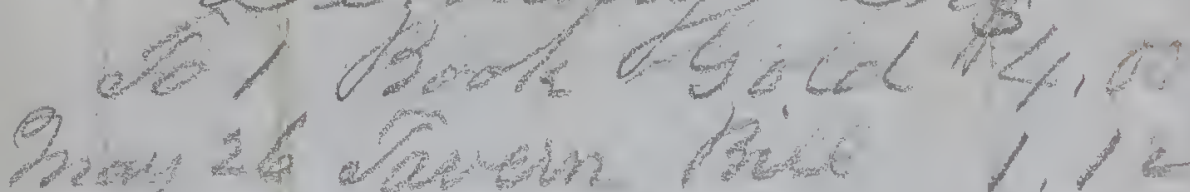

$$
\begin{aligned}
& 3 \% \text { 合 } \mathrm{BiLL} \\
& \text { 31 合 pill } \\
& \text { fune } 1 \text { Roult pare } 20 \\
& 6 \text { ic } \\
& 28 \\
& 24 \\
& \text { bill } \\
& 29 \\
& \text { a) } \\
& 37 \\
& 5 \\
& 3 \\
& 3 \\
& 50
\end{aligned}
$$




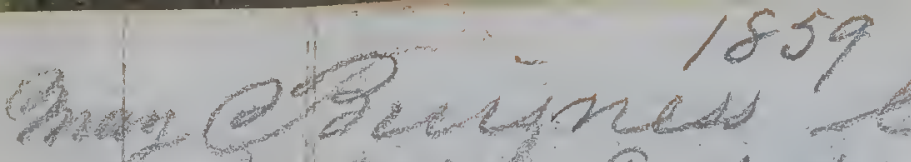

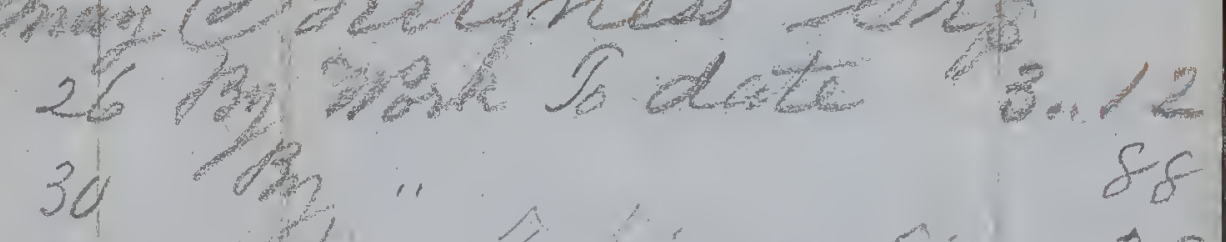

2x" gilling zade" 75 




SMITHSONIAN INSTITUTION LIBRARIES

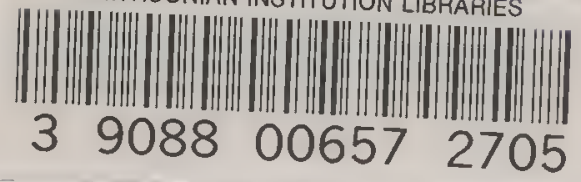


A

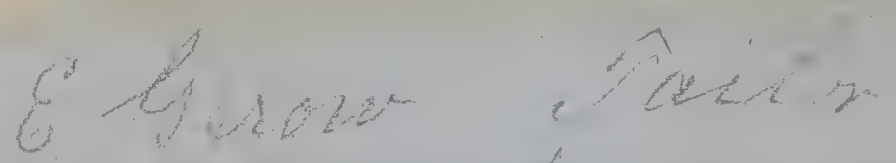

$$
\begin{aligned}
& \text { सtetentos } \\
& 1 \text { Treaco } \\
& 124
\end{aligned}
$$

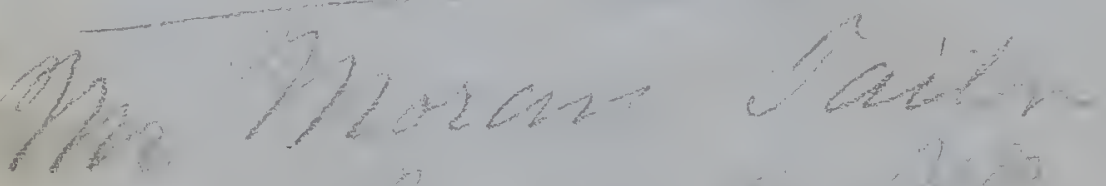

$$
\begin{aligned}
& \text { atod bap-i? }
\end{aligned}
$$

$1 / 17 k$

$\int^{1}-2+2$

$2+10$

Qunthandabe Orues ata

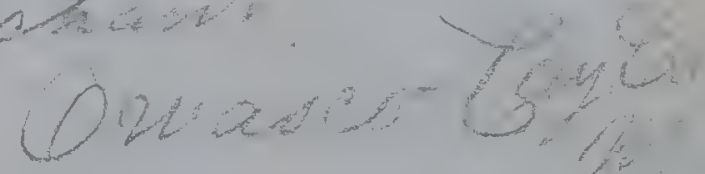


3
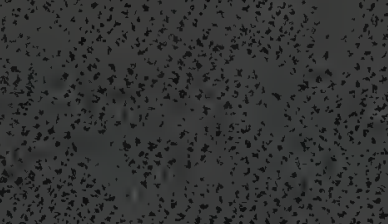

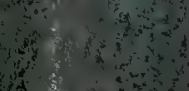
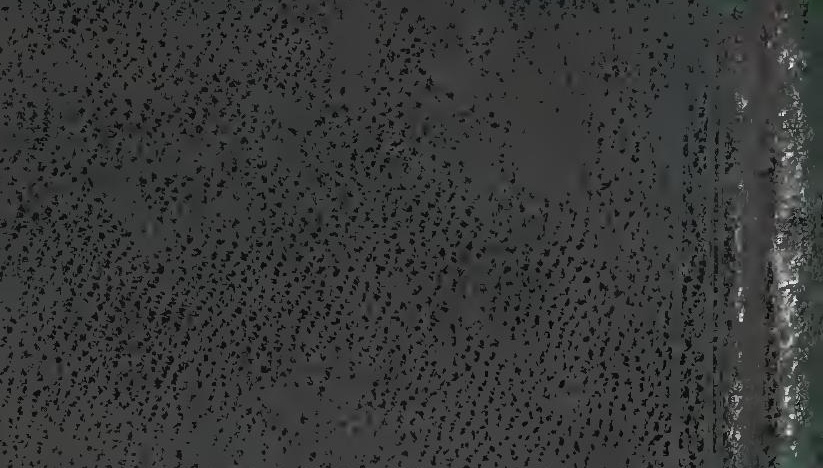

(3)

is

$\because$

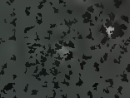

10

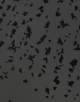

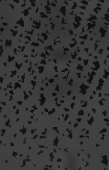

$3=1$ in

$\left(\frac{1}{3}+2\right.$

$B_{1}+3$

in

(x)

40 $\frac{3}{3}$

104

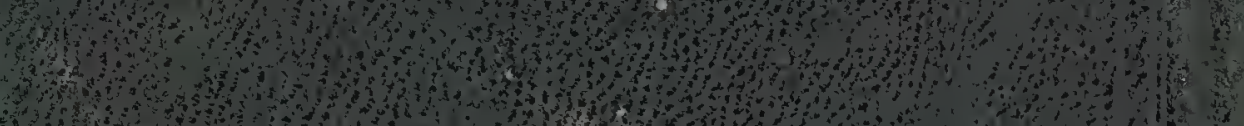
1360 (n)

frof (n)

40

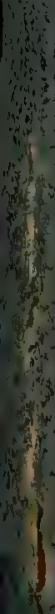

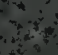

$$
\text { and }
$$

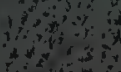

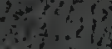

